\section{ANNUAL ADDRESS TO THE GEOLOGICAL SOCIETY OF LONDON, FEB. 16, 1872}

\section{By J. Prestwich, F.R.S., President}

\section{(Continued from pare 433.)}

T has been already mentioned that below a certain level permeable strata are necessarily always saturated and water-lozged, and that any additional quantity added to this constant quantity cannot be held permanently. It follows that wherever, in all water-bearing strata, after allowing for any abstraction, usually but comparatively small, by wells, the surplus rainfall must, when the stratum is full, find its escape by natura? means, i.e., by means of springs. The power and size of these are necessarily dependent upon the dimensions of the strata by which they are supplied. In the gravel they are small, in the Lower Tertiary sands moderate; while in the Chalk they are very large. The permanence of the spring depends on the lithological character as well as on the dimensions of the strata. Thus, in sands, where the water can permeate the mass, the stores are large, and the delivery moderately quick; in Limestones, where the water is confined to cracks and fissures, the delivery is quick and not lasting, though often large; in rubbly Oolites, which are also practically porous, the springs are well maintained; while in Chalk, owing to the characters before named, the water-delivery is slow, and the springs are large and very permanent.

At the same time the storage-capacity increases with the resistance. Taking the extreme case of the Chalk, the transmission of the rain-water is so slow, that, on the chalk hills, it takes four or six months to pass from the surface to the line of water-level at the depth of $200 \mathrm{ft}$, to $300 \mathrm{ft}$., so that the heavy rainfall of winter is not felt in the deep springs until the summer, and Mr. Beardmore estimates that the minimum effect of a hot dry summer and autumn is not reached until at the end of about sixteen months, or that the storing-power of the chalk is of sixteen months' duration. To estimate this power, we have to take the height and extent of the hills, and to note the lithological characters of the permeable strata. If these latter are underlaid by impermeable strata at above the level of the rivers in two adjacent valleys, then the base of the underground water-store will be coincident with the level of the impermeable strata, and its surface-line will rise, as it recedes within the hill, in proportion to the resistance offered to the water's escape by the character of the permeable strata, and it will thus form a curve between those two points, the height of which will vary in proportion to the rainfall. When, on the other hand, the permeable strata continue down to a greater or less depth beneath the surface of the adjacent rivers, then, as there is no underground escape for the stored water, the line of water-level in those permeable strata will rise to, and be always maintained at, the level of the rivers, and therefore all the additional sup. plies furnished by the rain must, after traversing the interior of the hills, find an escape along the bottom of the valleys, and by the side or in the bed of those rivers. In the dry upland valleys of the Chalk and Oolites, the underground water, dammed back by the streams in the nearest river-valley, passes under those valleys at depths varying with the resistance offered by the lithological character of the formation, and by the gradient of the valley as it runs into the hills.

When again, as in the case of the chalk downs and oolite hills, the exterior outcrop of the permeable strata rests on impermeable strata at a height above the river-levels, and in the other direction inwards they pass below similar levels, then the springs partake of the same divided character - the one smaller set flowing out on the sides of the hills, and the stronger and more lasting springs issuing, as it were, at the foot of the incline on the level of the rivers. In any case, it is the distance between the two points of escape that gives us one measure of storage. If the distance is reckoned by miles, then the rise of the waterlevel may be measured by tens of feet. It is highest when both the distance from the adjacent river-valleys, and at the same time the height of the hills is greatest. In some instances, the crown of the arch formed by it will rise to a height of from $60 \mathrm{ft}$. to $80 \mathrm{ft}$. above its chord.

This curve is subject to great fluctuation, varying according to the seasons and amount of rainfall. Mr. Clutterbuck has shown that, in the chalk hills of Hertfordshire, its height varies as much as $30 \mathrm{ft}$. or $40 \mathrm{ft}$. From the crown or centre of its summit it decreases at a rate varying generally from $3 \mathrm{ft}$. to $30 \mathrm{ft}$., or even more, per mile to all parts of the circumference. The height of the arch and the breadth of the base-line, taken together, give therefore the head of water supplying the large springs of the Chalk-such as those of Chadwell, Hoddesden, Otter, Carshalton, Leatherhead, Ospringe, and others. But, besides these, there are innumerable smaller ones, not so easily seen, flowing out on the sides, or in the beds of the rivers traversing the great permeable formations, as the many along the Thames from Greenhithe to Faversham, on the Upper Lea and its tributaries, and on the Medway and the Darent, where they traverse the chalk hills. This class of springs has especial geological bearings, which we shall hereafter have occasion to dwell upon.

The same general rutes govern the springs of all the more varied strata of the upper part of the Thames basin, where, in place of the Cretaceous and Tertiary series, we have a series of Jurassic and Liassic strata. Omitting the drift or gravel beds, the following are the average dimensions, character, and superficial areas of each of these formations in that area :-

Strata of the Thames Basin above Wallingrord

\begin{tabular}{|c|c|c|c|}
\hline & Area. & Average & Thickness. \\
\hline & $\begin{array}{l}\text { Square } \\
\text { miles. }\end{array}$ & $\begin{array}{l}\text { Permeable } \\
\text { strata. }\end{array}$ & $\begin{array}{c}\text { Impermeable } \\
\text { strata. }\end{array}$ \\
\hline Chall (above Kingston 1047) & 60 & $\ldots 1000$ & $\ldots \quad-$ \\
\hline Upper Greensands ... $\ldots$ & 62 & $\ldots \quad 100$ & $\ldots$ \\
\hline Gault $\quad \ldots, \ldots$ & 129 & - & 130 \\
\hline Lower Greensands ... & 23 & 200 & -2 \\
\hline Purbeck and Portland beds & 46 & 60 & - \\
\hline Kimmeridge Clay $\ldots \quad \ldots$ & 132 & - & 300 \\
\hline Coral Rag and grit... & 103 & 40 & - \\
\hline Oxford Clay $\quad \ldots \quad \ldots$ & 307 & $\ldots$ & 400 \\
\hline Great and Inferior Oolites... & 327 & $45^{\circ}$ & - \\
\hline Fuller's Earth $\quad \ldots \quad \ldots$ & 16 & - & 40 \\
\hline Lias ... & 170 & - & 500 \\
\hline
\end{tabular}

But although many of these water-bearing strata are of large dimensions and well stored in the upper part of the Thames basin, none of those below the Gault, except the Lower Greensand, are available for a well-supply at London. The Upper Greensand, so important in Wiltshire, is reduced to a few feet of compratively impermeable argillaceous sands under London. The Oolitic series, so rich in springs in the district of the Cotswold Hills, have been ascertained to thin off as they range eastward; and Mr. Hull has shown that the inferior Oolite and underlying sands in particular die out. in all probability, under the Oxford clay about the centre of Oxfordshire. Even apart, therefore, from the discovery made at Kentish Town, we should now have excluded the Oolitic series as a possible source of supply to deep wells in the London district; although, as sources of springs' supplies, they contribute so important a share to the maintenance of the Thames. Few of those strata are, however, so homogeneous as the Chalk and the London Clay. The permeable formations often contain subordinate impermeable clays-seams which form water-levels of more or less importance, whilst the impermeable clays sometimes contain subordinate beds of sand or of rock which constitute small local waterbearing beds. It is for the geologist to assign its relative value to each of these subordinate features, and to distinguish the minor from the major sources.

Taking the Thames basin above Kingston, there is, according to Mr. J. D. Harrison, an area of 1,233 square miles of impermeable strata, and of 2,442 miles of permeable strata, and the mean annual rainfall in that district amounts to about 27 inches. From the impermeable strata the rain flows off immediately as it falls, and is carried at once to sea; whereas a large portion of that which falls on the permeable strata is, as we have shown, stored for a greater or lesser time, and discharged in perennial springs. It is these which give permanence to our rivers. The evidence taken before the Commission showed that the daily discharge of the Thames at Kingston, even in the driest season after weeks without rain, never falls below $350,000,000$ gallons, while the average for the year gives, according to Mr. Simpson and Mr. Harrison, I, 353,000,000 gallons, or, according to Mr. Beardmore's longer observations, I, I45,000,000 gallons daily, the mean of $1,250,000,000$ gallons being equal to a fall of about 8 in., or rather less than one-third of the annual quantity, the other two-thirds being lost by evaporation and absorbed by the vegetation. This seems the proportion usual under the like general conditions in these latitudes. M. Belgrand has shown, in "La Seine," that in the upper basin of the Seine there are I 9,390 square kilometres of impermeable, and 59,2 ro of per 
meable strata; and careful measurements have proved that the discharge at Paris is also equal to about one-third of the rainfall. The exact proportion of the rainfall passing into the different permeab!e strata, and given out again in the form of springs, has yet to be accurately determined. Mr. Harrison estimates it in the Thames basin at about one-sixth of the rainfall.

In districts where impermeable strata predominate, the total water delivery, therefore, will be greater; but it follows close upon the rainfall; whereas, where the permeable strata predominate, a large portion of the rainfall is stored in the hills, and its delivery is thereby spread over a greater or lesser period of time, according to the dimensions of those hills. This is well exemplified in the case of the basins of the Thames and the Severn, which latter is formed in large part by the slate rocks of Wales. The former has an area above Kingston of 3,670 square miles, with an annual rainfall of $2 \%$ inches; whereas that of the latter above Gloucester has an area of 3,890 miles, with an average rainfall of probably not less than 40 inches, and the mean daily discharge for the year is for the Thames of " $1,250,000,000$ gallons, and for the Severn about $I, 600,000,000$ gallons. Yet the summer discharge of the Thames averages $688,700,000$ gallons daily, against $297,599,040$ gallons of the Severn; and while the minimum discharge of the Thames in the driest seasons never falls below 350,000 ,000 gallons, that of the Severn falls below 100,000,000 gallons. Again, in the case of the Lea, where there is a still larger proportion of permeable strata, the daily discharge at Broxbourne for the year is, according to $\mathrm{Mr}$. Beardmore, 108,000,000 gallons, while for the summer months it remains as high as $71,000,000$, and in the driest seasons does not fall below $42,000,000$ gallons.

Let us now look at one of the geological questions dependent upon the solvent action of the water on the strata it traverses. The analyses, made for the Commission by Drs. Frankland and Odling, of the waters of the Thames and its tributaries in the Oo.itic and Chalk area, show that every 100,000 parts or grains of rainwater has taken up a quantity varying from 25.58 to 32.95 grains of solid residue, or an average of 29.26 , which is equal to 20.48 parts or grains per gallon; another analysis of the Thames water at Ditton gives 20.78 grains per gallon of solid residue. It was also shown by 'Drs. Letheby and Odling and Prof. Abel that the unfiltered waters of the Thames Companies, which take their supplies above Kingston, contained 20.82 of solid residue, If from the average of $20^{\circ} 68$ we deduct 1.68 grain for organic and suspended matter, we have 19 grains of inorganic residue for every gallon of water flowing past Kingston. This is of course apart from the sediment carried down in floods. The ordinary montbly analyses; conducted by the same eminent chemists during the course of several past years, show that this quantity is liable to very little varialion, the only difference being that it is somewhat larger in winter and less in summer.

Some general estimates have already been made by: Profs. Ransay and Geikie of the quantity of mineral matter carried down in solution by the Thames ; but the more exact data supplied to the Commission enable us to make some additions to previous results. Taking the mean daily discharge of the Thames at Kingston at I, 250 million gallons, and the salts in solution at 19 gains per gallon, the mean quantity of dissolved mineral matter there carried down by the Thames every twentyfour hours is equal to $3,364,286 \mathrm{lbs}$, or 1502 tons, or 548,230 tons annually. Of this daily quantity about two-thirds, or $1 ; 000$ tons, cinsist of carbonate of lime, and 238 tons of sulphate of lime, while imited proportions of carbonate of magnesia, chlorides of sodium and potassium, sulphates of soda and potash, silica and traces of iron, alumina, and phosphates, constitute the rest. If we refer a small portion of the carbonates, and the sulphates and chlorides chiefly, to the impermeable argillaceous fo:mations washed by the rain water, we shall still have at least ro grains per gallon of carbonate of lim ; due to the Cretaceous and (Jolitic strata and Marlstone, the superficial area of which, in the Thames basin atore Kingston, is es?imated by Mr. Harrison at 2,072 square miles. Therefore the annual quantity of carbonate of lime carried away from this area by the Thames is $29090 ;$ tons, or 797 tons daily, which gives 140 tons removed yeariy fr.m each square mile; or extending the calculation to a century we have 14.000 tons rmoved from each mile of surface. Taking a ton of chalk as equal to 15 cubic feet, this is equal to a removial of $\frac{9}{100}$ of an inch from the surface in the course of a century, so that in the course of 13,200 y ars a quantity equal to a thickness of about one foot would be removed from our Chalk and Oolitic districts.
I had some faint hope that this wear might furnish us with a rough approximate measure of time in reference to some of the phenomena connected with the Quaternary period; but we are not in a position to apply it. Those curious funnel-shaped cavities, called sand and gravel-pipes, so common in many chalk-districts, are the result of slow solution of the chalk by water at particular spots, whereby the superincumbert sand and gravel have been let down into the cavity so produced. Some of them are but a few feet deep, while others attain dimensions of 80 feet in depth by 15 to 20 feet in diameter at top, tapering irregularly to a point at bottom. It is, however, evident from the variation in size that the wear has been unequal; and it is also clear that the surface-waters have been conducted through these particular channels, where they existed, to the underground water-level, in preference to passing through the body of the chalk, so that the ratio of wear at these points is in excess. Nor can $\{$ see at present how otherwise to apply this measure. If it were possible to find a spot where the exposed surface of the chalk has been worn uniformly, and, from the quantity of flints left after the removal of the chalk and the known distance apart there of the seams of flint, to determine the number of feet or inches re moved, we might have a base to proceed upon, provided all the quantities remained constant. But such is not the case. Also, although the annual rainfall in the Thames now averages 27 inches, and has probably not varied much from this amount during the present period, it was eviden'ly much greater during the Quaternary period; for I have elsewhere shown that, in the South of England and North of France the rivers of those areas with the same catchment-basins were of much greater size than at present; and $\mathrm{Mr}$. W. Cunnington had before pointed out the same fact in the upper part of the basin with respect to some of the rivers of Wiltshire. M. Belgrand has made an attempt to estimate this quantity with reference to the Seine and its tributaries, and he arrives at the conclusion that, during the Quaternary (or, as he considers it, the Glacial) period, the rainfall was so heavy, that the discharge of the river was from 20 to 25 times greater than at prisent. I do not altogether concur in this view, but I can conceive that our rivers formerly were of five or six times the size they now are. This is an important element to be considered in all questions bearing on the denudation of Jand-surfaces.

There is yet another point which, although not in our direct field of research, yet depends so essentially upon the geological conditions we have discussed, and is one, in a public point of view, of such paramount importance, that I will, with 'your permission, say a few words on the subject. In an uninhabited country, the rain passes through the soil and issues as springs, bearing with it a certain proportion of mineral matter, and only traces of such organic matter as existed on the surface. This would be solely of vegetable origin, and the proportion would be in most cases very small. As man appeared, those conditions would be at first but little altered, for animal matters exposed on the surface rapidly decay and pass away in a gaseous form; but with increasing civilisation and fixed residences the necessity of otherwise getting rid of all refuse would soon be felt. I have shown how population followed the range of shallow permeable strata and the course of valleys, $s o$ as to obtain readily that indispensable necessity of life, a sufficient water supply. But with the art of well-digging it soon became apparent that, let the well be carried down but half way to the level of ground-springs, it would remain dry, and that then, so far from holding water, any water now poured into it would pass through the porous strata down to the water-level beneath, keeping the shallower well or pit constantly drained. So convenient and ready a means of getting rid of all refuse liquids was not neglected. Whilst on one side of the house a well was sunk to the ground-springs, at a depth, say, of twenty feet, on the other side a dry weil was sunk to a depth of ten feet, and this was made the receptacle of house-refuse and sewage. The sand or gravel acting as a filter, the minor solid matter remained in the dry well, while the major liquid portion passed through the permeable stratum and went to feed the underlying springs. What was done in one house was done in the many; and what was done by our rude ancestors centuries back has continued to be the practice of their more cultivated descendants to the present day, with a persistency in the method only to be attributed to the ignorance of the existence of such a state of things among the masses, and to the ignorance of the real conditions and actual results of perpetuating such an evil-an evil common alike to the cottages of the poor and, with few exceptions, to the mansions of the rich. 
Instances occur from time to time to point out isolated consequences of this pernicious practice, but $I$ believe no one who has not gone into the geological question can realise its magnitude. It is not confined to one district or to a few towns or villages. It is the rule, and only within the last few years have there been any exceptions. The organised supply of water now furnished by companies in all large towns has, to a great extent, done away with the evil in those situations (though the root of the mischief has too often been left unextracted); but in villages and detached houses, great or small, it remains untouched and unchecked. Not a county, not a district, not a valley, not the smallest tract of permeable strata, is free from this plague-spot. It haunts the land, and is the more dangerous from its unseen, hidden, and too often unsuspected existence. Bright as the water often is, without objectionable taste or smell, it passes without suspicion until corrupted beyond the possibility of concealment by its evil companionship. Damage, slight in extent; or unim. portant possibly for short use, but accumulative by constant use, may and does, I believe, pass unnoticed and unregarded for years: Nevertheless the draught, under some conditions, is as certain in its effects, however slow in its operation, as would be a dose of hemlock: Go where we may, we never know when the poisoned chalice may be presented to our lips. The evil is selfgenerating ; for the geological conditions supplying our necessities lend themselves to its maintenance and extension. The knowledge necessary to remedy it is of very slow growth, and the too frequent want of that knowledge, or disregard of the subject, even amongst able architects and builders, is such that, without legislative enactment, I do not see how the evil is to be eradicated for many a long term of years.

This also is only one form of the evil-it is that where the water-bearing strata are thin and the wells do not exceed a depth of thirty feet. It was the one which prevailed in London, and in towns similarly situated, up to a very few years back. It even still lingers on in some private wells, and is moreover fostered among us by the bright-looking and cool water of too many of our public pumps; for not only does the ground still suffer from the effects of the original contamination, but also from much, almost inevitable, obnoxious surface-drainage, much gas escape, much rainfall on old open churchyards, which find their way to the one level of water supplying in common all these shallow wells: The evil still exists also, although to a less extent, in towns where the wells have to be carried to much greater depths ; its effects varying according as the depth, and as the volume of the springs is to the sewage-escape; it is, however, only a ques: tion of degree.

But even our deeper and apparently inaccessible springs have not escaped contamination. As before mentioned, the underground water will, when tapped by artesian wells, rise to or above the surface, according to the relative height of the surface of the ground at the well, and of the outcrop of the water-bearing bed or beds, so that if the former is higher than the tlatter, or if by artificial means the line of water-level in a given area becomes lowered, then the surface of the water belonging to those great underground natural reservoirs will be established accordingly at a certain fixed depth beneath the surface. As each well deriving its supply in a stratum of this description represents a column of water communicating with one common reservoir, it follows that any cause permanently lowering the level of one well will tend to lower the level in the other wells in proportion to their number and distance. Further, it has been discovered that a well of this class can absorb a quantity of water equal to that which it can furnish; and as these wells give greater supplies than shallow wells, the absorbing wells of the same class are alike powerful in proportion to the others. The perverse ingenuity of man has here, again, taken advantage of these conditions to get rid of offensive waste waters by diverting them into such deep wells, whence they pass away in hidden underground channels, unseen and unsuspected, and mingle with those deep-seated water-sources feeding the artesian wells dependent upon them for their supply.

In Paris, where there are several alternating beds of permeable and impermeable strata, and the depth to reach them is not very great, this system of absorbing wells connected with factories became, until regulated by the inunicipality, very common, to the great injury of many of the underground springs. From this and the other causes before alluded to, a great number of shallow wells have there become so contaminated as to necessitate their abandonment. . Our own system of surface-drainage is generally too good, and the depth to the lower water-bearing strata too great, to have rendered the use of such wells here equally advantageous; nevertheless, I have reason to believe that they do exist, and that the sources even of our deep wellwater supply in the Lower. Tertiary Sands and in the Chalk are thus to some extent polluted and injured.

Nor do the great and perennial springs supplying our rivers altogether escape the evils arising from these obnoxious practices. On the high Oolitic ranges and amongst the undulating Chalk hills, the line of water-level is often so deep below the surface, that only in few cases are wells made-the population being generally dependent on rainwater for their water-supply. But this does not prevent the construction of dry wells for the disposal of sewage and refuse. It is true that the population in these hills is sparse--here and there a farm, a few cottages, and scarcely a village. Still as the ground is everywhere absorbent, and there are no streams even in the valleys (I am now speaking of the higher districts), every dwelling contributes its quota; for the rain and all liquid matter absorbed in these strata necessarily pass down to the great underground reservoirs of water feeding the springs thrown out in the deeper river-valleys. In these cases, however, the thickness of strata through which any liquid has to pass before reaching the line of water-level is such as to produce a more or less efficient filtration and complete decom: position; and as the injury caused is in proportion to the relative volumes of the water-sources and to the artificial additions, the great extent and dimensions of these water-bearing strata and the scanty population of such districts reduce it to a minimum.

Oxing to these conditions, great as the evil is, experience teaches that it has, in some cases, its vanishing-point. It may be considered at its maximum in some of the wells of Paris ; our own London shallow-well pumps follow next in order; in our river-waters away from towns it is but slight; in some of the springs of the Chalk and Lower Greensands it is hardly appreciable, while in the deep well-waters, especially those of Caterham and Grenelle, it sinks to the minimum attained by any potable waters, with the exception of rain-water. It is also a fortunate circumstance that the wonderful powers of oxidation possessed by air and water, and the powers of absorption and decomposition by soils and earths, are such as, even in the surcharged gravel-bed of London, to remove all the more offensive characters, and leave its spring-waters at all events limpid and bright; whilst the quick eddy, the moving ripple, the bright sunshine, the brisk breeze, the living organisms, are ever at work in our rivers, destroying the almost inevitable accompaniments of the presence of man, and restoring the waters to that original state of purity so essential to his health and welfare.

It was on considerations of quantity of supply thus dependent on geological conditions, and of quality as dependent jointly on geological and artificial conditions, that the Commission was mainly so long and assiduously engaged. With regard to the character of waters as dependent on the geological nature of the strata, while the evidence showed that the waters flowing off hard and insoluble rocks were, from their much greater freedom from mineral matter, more economical for many domestic and manufactuxing purposes, yet that for drinking purposes, waters such as those derived from our Chalk and Oolitic districts . were, on the whole, as good and wholesome as those from any other sources - while as regards quantity and permanence, the conditions presented by a large catchment basin of a varied geological structure presented the most favourable conditions for the large and maintained supply so essential for a great city. And if, from any cause, it should at some future time be thought desirable to have a supply of a yet more assured and undoubted quality than a river supply, the large springs of the chalk and the Lower. Greensand, or the great underground reservoirs of the most efficiently filtered water stored in those formations in Surrey and Hertfordshire, might, I believe, be resorted to with advantage, by means of ordinary and artesian wells, as auxiliary sources of supply for domestic and drinking purposes, supposing the engineering difficulties connected with a double water-supply could be overcome-a difficulty which it, however, seems to me would possibly be less one of construction to our engineers than of cost to the public. But in a great health-question there are other considerations than these which are of more primary importance.

(To be continued.)

\section{SCIENTIFIC SERIALS}

Fournal of the Franklin. Institute, November 187\%. The editorial notes in this number are as usual very instructive; 